\title{
Release of Adenosine from Human Hearts
}

\section{during Angina Induced by Rapid Atrial Pacing}

\author{
Arthur C. Fox, George E. Reed, Ephraim Glassman, \\ Alfred J. Kaltman, and Barbara B. Silk \\ From the Departments of Medicine and Surgery, New York University School \\ of Medicine, 550 First Avenue, New York 10016
}

\begin{abstract}
A B S TRACT This study was designed to determine whether human hearts release adenosine, a possible regulator of coronary flow, during temporary myocardial ischemia and, if so, to examine the mechanisms involved. Release of adenosine from canine hearts had been reported during reactive hyperemia following brief coronary occlusion, and we initially confirmed this observation in six dogs hearts. Angina was then produced in 15 patients with anginal syndrome and severe coronary atherosclerosis by rapid atrial pacing during diagnostic studies. In 13 of these patients, adenosine appeared in coronary sinus blood, at a mean level of $40 \mathrm{nmol} / 100 \mathrm{ml}$ blood ( $\mathrm{SE}= \pm 9$ ). In 11 of these 13 , adenosine was not detectable in control or recovery samples; when measured, there was concomitant production of lactate and minimal leakage of $\mathrm{K}^{+}$, but no significant release of creatine phosphokinase, lactic acid dehydrogenase, creatine, or $\mathrm{Na}^{+}$.

There was no detectable release of adenosine by hearts during pacing or exercise in three control groups of patients: nine with anginal syndrome and severe coronary atherosclerosis who did not develop angina or produce lactate during rapid pacing, five with normal coronaries and no myocardial disease, and three with normal coronaries but with left ventricular failure.

The results indicate that human hearts release significant amounts of adenosine during severe regional myocardial ischemia and anaerobic metabolism. Adenosine release might provide a useful supplementary index of the early effects of ischemia on myocardial metabolism, and might influence regional coronary flow during or after angina pectoris.
\end{abstract}

A preliminary abstract of this work appeared in: 1971. Circulation. 44(Suppl. II) : 65.

Received for publication 3 August 1973 and in revised form 29 November 1973.

\section{INTRODUCTION}

In human hearts with restricted coronary circulation, temporary increases in oxygen needs can produce angina pectoris, changes in electrical repolarization, and the release of lactate and potassium into coronary venous blood (1). In animals, temporary myocardial ischemia has also been shown to cause release of inorganic phosphate (2) as well as adenosine, inosine, and hypoxanthine (3). The release of adenosine is of particular interest, both as an index of the effects of ischemia on myocardial purines and as a possible regulator of coronary blood flow. Adenosine is a potent coronary vasodilator, has a rich pool of precursors within myocardial cells, readily crosses cell membranes, is quickly degraded, is present in the well oxygenated myocardium at low basal levels, and increases during ischemia (3, 4, $5)$. The nucleotide precursors of adenosine are more potent vasodilators (6), but do not diffuse freely from normal cells; the degradation products of adenosine, inosine and hypoxanthine, are diffusible but do not increase coronary flow (3).

Adenosine appeared in coronary sinus (CS) ${ }^{1}$ blood when reactive hyperemia was induced in canine hearts by transient coronary occlusion (3). Although there is no direct evidence that adenosine increases coronary flow in man, dipyridamole, which inhibits the uptake and degradation of adenosine by cells, is a potent coronary vasodilator (7).

In these studies, we initially confirmed the observation that, in dogs, adenosine appears in CS blood after transient ischemia, and then we examined an analogous situation in man. In patients with severe coronary athero-

${ }^{1}$ Abbreviations used in this paper: c-AMP, cyclic 3'5'AMP ; CPK, creatine phosphokinase ; $\mathrm{Cr}$, creatine ; CS, coronary sinus; $L D H$, lactic acid dehydrogenase; $P_{1}$, inorganic phosphate. 
sclerosis, we found that adenosine was released in significant amounts when angina and concomitant lactate production were induced by rapid atrial pacing.

\section{METHODS}

\section{Studies in dogs}

Studies were preliminary and were designed to perfect techniques and to confirm earlier work (3). CS blood (75$140 \mathrm{ml}$ ) was collected from open-chest animals during control periods and during evident reactive hyperemia induced by transient tightening of coronary arterial ligatures. CS blood was also collected after production of myocardial infarction, to demonstrate that rises in serum creatine phosphokinase (CPK), lactic acid dehydrogenase (LDH), and creatine $(\mathrm{Cr})$ could be detected by our methods.

\section{Studies in man}

Studies were made during routine diagnostic cardiac catheterizations, performed with the informed consent of the patients. These studies did not interfere with, nor unduly delay, requisite procedures. Four groups were studied, group A: patients with histories of angina pectoris and with significant (at least $75 \%$ ) obstruction of one or more major coronary arteries, as demonstrated by selective angiography, who developed definite angina pectoris on pacing; group B: patients with similar histories and similar degrees of coronary artery disease who developed no angina or only questionable chest discomfort on pacing; group C: patients with no significant coronary artery disease or hemodynamic abnormalities who were catheterized because of questionable angina or heart disease; group $D$ : patients with no coronary artery disease who were in severe heart failure.

Coronary venous blood was obtained through a no. 7 pacing catheter positioned in the $C S$ at $2 \mathrm{~cm}$ beyond the orifice. Six samples of $15 \mathrm{ml}$ were rapidly drawn into syringes containing $25 \mathrm{ml}$ of chilled heparinized saline. Angiographic procedures followed sampling of blood, since even small amounts of the contrast medium, meglumine diatrizoate, interfered with separation of nucleosides by chromatography. Femoral arterial blood was sampled through cannulas inserted by the Seldinger technique.

The ventricular rate was accelerated by increments of 10 beats/min until definite anginal pain or atrioventricular block appeared. The intensity of the anginal pain relative to the patient's previous pain pattern was evaluated through close questioning by two observers and was roughly scored on a scale of $1+$ to $4+$. Pacing was continued in most experiments for 1-2 min during the rapid collection of CS blood. In a few instances, when angina was very severe, the rate was lowered and collection of CS blood was rapidly completed as pain subsided. When anginal pain did not appear or was questionable and unaccompanied by electrocardiographic changes, pacing was continued at rates between 140 and $180 / \mathrm{min}$ for $10 \mathrm{~min}$ and collections were made during continued tachycardia.

Control samples of $90 \mathrm{ml}$ of CS blood were collected in an identical fashion for measurement of adenosine, either before pacing or at $10 \mathrm{~min}$ after complete recovery from angina. Heart rates during these collections were always at resting levels, and were generally less than half the rate required to produce angina. In two patients with no coronary artery disease who were included as controls, exercise on a bicycle ergometer was substituted for atrial pacing during hemodynamic studies and caused similar increases in heart rate.

For measurement of lactate before, during, and after angina, samples of blood from the CS and the femoral artery were simultaneously collected into cold $6 \%$ perchloric acid. Small samples of CS blood were also collected for measurement of $\mathrm{CPK}, \mathrm{LDH}, \mathrm{Cr}$, cyclic $3^{\prime}, 5^{\prime}$-AMP (cAMP), inorganic phosphate $\left(P_{1}\right), \mathrm{Na}^{+}$, and $\mathrm{K}^{+}$.

\section{Analytic techniques}

Rapid processing of blood samples was essential to minimize uptake of adenosine by red cells. The procedure was modified from that described by Rubio, Berne, and Katori (3). The diluted samples of chilled heparinized blood were centrifuged at $4^{\circ} \mathrm{C}$ for $5 \mathrm{~min}$ at $1,800 \mathrm{~g}$. The supernates were heated at $100^{\circ} \mathrm{C}$ for $10 \mathrm{~min}$ to denature proteins, which were separated at $24,500 \mathrm{~g}$. Samples had to be concentrated considerably because of the low concentrations of adenosine in human blood. The supernate and washings of the precipitates were ultrafiltered through a Diaflo UM-2 membrane (Amicon Corp., Lexington, Mass.) to remove material over mol wt 1,000 . This improved adsorption of the nucleosides contained in $90 \mathrm{ml}$ of blood onto $2 \mathrm{~g}$ of highly purified Norite A charcoal. The charcoal was collected on a no. 40 Whatman filter and washed with water until free of salts; nucleosides were eluted by shaking in $3 \% \mathrm{NH}_{4} \mathrm{OH}-60 \%$ ethanol for $10 \mathrm{~h}$ at $37^{\circ} \mathrm{C}$. The charcoal was washed with ethanol to remove all material absorbing at $260 \mathrm{~nm}$, and fine particles were removed by filtration through a Millipore membrane. Filtrates were flash-evaporated to dryness and redissolved in 1 or $2 \mathrm{ml}$ of $50 \%$ ethanol at $\mathrm{pH} 10$. Either all or one half of this was streaked on thin layer $(0 / 5 \mathrm{~mm})$ plates of the ion exchange resin, Selectacel-P (Schleicher and Schuell, Inc., Keene, N. H.), and developed at $4^{\circ} \mathrm{C}$ with $15 \%$ ethanol at $\mathrm{pH}$ 7.0. Separated nucleosides were identified under UV light by their migrations relative to known standards and were eluted. Eluates were lyophilized in test tubes and redissolved in $\mathrm{H}_{2} \mathrm{O}$ or in $0.05 \mathrm{~N} \mathrm{NaOH}$ for hypoxanthine. The identity and purity of each eluted streak was confirmed on a second plate by development with $25 \%$ ethanol at pH 10 . When eluates showed background absorbance which interfered with the spectrophotometric assay, unidentified blood chromagens were further removed by a second development.

Adenosine. Adenosine was measured with a micromodification of the adenosine deaminase technique described by Kalckar (8). Assays were made with a Beckman D-U spectrophotometer (Beckman Instruments, Inc., Fullerton, Calif.), using a reaction mixture of $400 \mu 1$ and sample volumes of 50 or $100 \mu \mathrm{l}$, representing $1 / 4$ to $1 / 16$ of the original sample. Accurate measurement required changes in absorbance at $260 \mathrm{~nm}$ greater than $0 / 01$. The enzymatic technique could precisely measure $1.0 \mathrm{nmol}$ of adenosine. Standards containing $10 \mathrm{nmol}$ of adenosine were measured enzymatically during each experimental assay and were regularly recovered at $90 \%$ or more. Duplicate enzymatic assays of all experimental samples agreed to within $10 \%$. The assay was linear with respect to concentration and was not affected by addition of ATP, ADP, or AMP, which were well separated from adenosine during thin layer chromatography.

\section{Recoveries of adenosine standards}

Adenosine added to saline. Adenosine added to saline at levels of 60,100 , and $120 \mathrm{nmol} / 100 \mathrm{ml}$ was carried through the concentration process and recovered in a range of 
$65-80 \%$. Studies with $\left[{ }^{14} \mathrm{C}\right]$ adenosine showed that most losses occurred during elution from charcoal and during flash evaporation.

Adenosine added to human blood. Adenosine added to human blood was recovered in a range of $42-55 \%$, corresponding to the results of others (3). To duplicate experimental conditions, standards were added to saline in the syringes used to collect systemic venous blood. The individual rates of recovery were: (a) $95 \mathrm{nmol} / 90 \mathrm{ml}$ (four studies) : 53 and $50 \%$ from duplicate samples; 47 and $44 \%$ from duplicate samples, (b) $80 \mathrm{nmol} / 30 \mathrm{ml}$ (one study) : $55 \%$, (c) $60 \mathrm{nmol} / 30 \mathrm{ml}$ (two studies): 50 and $46 \%$ from separate samples, (d) $26 \mathrm{nmol} / 90 \mathrm{ml}$ (two studies) : $42 \%$ from duplicate samples, (e) $11.8 \mathrm{nmol} / 90 \mathrm{ml}$ (two studies): 46 and $48 \%$ from duplicate samples. Recoveries from whole blood were not improved significantly by addition of dipyridamole alone or in combination with inhibitors of adenosine deaminase such as $p$-chloromercuribenzoate, 8-azaguanine, or sodium mercaptomerin. Concentrations of adenosine below $10 \mathrm{nmol} / 100 \mathrm{ml}$ of blood were detectable but could not be reliably measured, despite the sensitivity of the enzymatic assay, because of the high background absorbance of the blood concentrates. No adenosine was detected in systemic venous blood in two duplicate samples of $90 \mathrm{ml}$ or in four separate samples of $40 \mathrm{ml}$ each. Adenosine was not detected in dilute hemolysates prepared from two samples of $10 \mathrm{ml}$ of human blood.

Inosine and hypoxanthine. Inosine and hypoxanthine were qualitatively identified on the thin layer plates but were not regularly eluted and measured enzymatically, since our principal concern was to identify adenosine, the vasoactive nucleoside. Recoveries of $300 \mathrm{nmol}$ standards of these nucleosides from two $90-\mathrm{ml}$ samples of whole blood were 60 and $70 \%$.

Lactate, creatine, and serum $\mathrm{Na}^{+}$and $\mathrm{K}^{+}$. Lactate was measured enzymatically in duplicate samples of deproteinized blood (9); the values were averaged and reported as the conventional lactate extraction ratio, $(\mathrm{A}-\mathrm{CS} / \mathrm{A}) \times 100$. Negative values for this ratio, or a marked shift from previously positive values, indicate production of lactate by the heart. Creatine was measured enzymatically (10) in plasma samples which were rapidly separated from chilled blood, ultrafiltered, and extracted repeatedly with ether to remove pyruvic acid (11). Results from duplicate samples agreed within $90 \%$. CPK and $\mathrm{LDH}$ were measured enzymatically in duplicate $(10,12)$. Normal values for $\mathrm{LDH}$ were from 100 to $350 \mathrm{U} / \mathrm{ml}$, and for CPK from 0 to 12 $\mathrm{U} / \mathrm{ml}$ of serum. Serum $\mathrm{Na}^{+}$and $\mathrm{K}^{+}$were measured by flame photometry using lithium as an internal standard.

The levels of these substances in CS blood during angina pectoris were compared with levels found during control or recovery periods in each patient and evaluated both as pairs and in groups by Student's $t$ test.

$P_{1}$ and $c-A M P . \mathrm{P}_{1}$ was measured in protein-free filtrates of serum by the colorimetric stannous chloride method (13), with a reproducibility of $95 \%$. c-AMP was measured in deproteinized serum by competitive protein binding (14); the normal mean level in systemic venous serum was 39.8 $\mathrm{pmol} / \mathrm{ml}(\mathrm{SE} \pm 7.8)$.

\section{RESULTS}

\section{Studies in dogs}

In six animals studied during reactive hyperemia, adenosine was found in CS blood at levels similar to those reported by Rubio et al. (3). Inosine and hypoxanthine were qualitatively identified in all hyperemic samples but were assayed enzymatically in only two studies; the levels again approximated those reported earlier (3). Cr was measured in three animals during reactive hyperemia and was not increased. After production of myocardial infarction in these and other animals, $\mathrm{CPK}$ and $\mathrm{LDH}$ rose sharply, and $\mathrm{Cr}$ doubled in $\mathrm{CS}$ blood.

\section{Studies in man}

\section{Group A}

Angina pectoris. Angina pectoris was induced by rapid atrial pacing in 14 patients with positive clinical histories (Table I). In one patient with severe unstable angina, pain occurred spontaneously (Table I, no. 10). Changes in electrical repolarization usually accompanied angina. All patients had severe obstructive coronary artery disease. Patients 3, 4, 8, 13, and 14 had significant stenosis of three major coronary arteries; patients 1 , $2,6,7,9,10,11,12$, and 15 had significant stenosis of two; patient 5 had significant stenosis of one artery.

Adenosine. Adenosine was found in CS blood sampled from 13 of these 15 patients during angina (Table I) in significant concentrations ranging from 5 to 120 $\mathrm{nmol} / 100 \mathrm{ml}$ of whole blood. No adenosine was found in CS blood from one patient (no. 8) during definite anginal pain; in another patient (no. 2), an amount was found which was at the lower limits of detection by the analytic technique. Control samples of CS blood were collected from nine patients before pacing and from four patients at $10 \mathrm{~min}$ after complete recovery from angina. Adenosine was detectable before pacing only in patient no. 5 , and at a low concentration; it persisted after recovery from pain only in the patient with spontaneous angina.

Lactate, $\mathrm{CPK}, \mathrm{LDH}, \mathrm{Na}^{+}$, and potassium. Lactate was produced in significant amounts during angina by 12 of the 13 patients in whom it was measured, as indicated by a shift to a negative or markedly decreased myocardial lactate extraction ratio. All patients who produced adenosine produced lactate concomitantly, when it was measured (Table I, Fig. 1). However, patients nos. 8 and 2, who released no adenosine or a trivial amount during angina, nevertheless produced significant amounts of lactate. Patient no. 13 continued to produce lactate after recovery from angina (Table I, Figure 1). CPK, $\mathrm{LDH}$, and $\mathrm{Na}^{+}$in CS blood did not increase significantly during angina. Potassium was slightly higher in CS blood during angina in 10 of 13 patients in whom paired samples were examined; the differences between paired samples were of borderline significance, with $P<$ 0.05. Arterial levels were not measured. $\mathrm{Cr}$ was higher in CS blood during angina in 7 of 13 patients studied, but the increases were not statistically significant. 
TABLE I

Patients with Anginal Syndrome and Severe Coronary Atherosclerosis: Definite Angina and Production of Lactate Induced by Rapid Atrial Pacing

\begin{tabular}{|c|c|c|c|c|c|c|c|c|}
\hline \multirow[b]{3}{*}{ Patient } & \multirow[b]{3}{*}{ Conditions* } & \multicolumn{7}{|c|}{ cs } \\
\hline & & \multirow[b]{2}{*}{ Adenosine } & \multirow[b]{2}{*}{ Lactate } & \multicolumn{2}{|c|}{ Enzymes } & \multirow[b]{2}{*}{ Creatine } & \multirow[b]{2}{*}{$\mathrm{Na}^{+}$} & \multirow[b]{2}{*}{$\mathbf{K}^{+}$} \\
\hline & & & & CPK & LDH & & & \\
\hline & & $\begin{array}{l}\text { nmol/ } \\
100 \mathrm{ml} \\
\text { blood }\end{array}$ & $\begin{array}{c}(A-C S / A) \\
\times 100\end{array}$ & \multicolumn{2}{|c|}{$U / m l$ serum } & $\begin{array}{c}\text { Amol/100 ml } \\
\text { plasma }\end{array}$ & \multicolumn{2}{|c|}{ meq/liter serum } \\
\hline 1. $M, 63$ & $\begin{array}{l}\text { Angina } \\
\qquad(3+, 130)\end{array}$ & 9 & & & & & & \\
\hline 2. $M, 64$ & $\begin{array}{l}\text { Angina } \\
\quad(2+, 150) \\
\text { Recovery }\end{array}$ & 2 & $\begin{array}{l}-21 \% \\
+1 \%\end{array}$ & 2.67 & & & 146 & 4.5 \\
\hline 3. F, 67 & $\begin{array}{l}\text { Control } \\
\text { Angina } \\
\qquad(4+, 180)\end{array}$ & $\begin{array}{c}\text { ND } \ddagger \\
76\end{array}$ & - & $\begin{array}{l}2.10 \\
2.90\end{array}$ & $\begin{array}{l}216 \\
162\end{array}$ & & $\begin{array}{l}130 \\
132\end{array}$ & $\begin{array}{l}5.8 \\
5.7\end{array}$ \\
\hline $\begin{array}{r}\text { 4. } \mathrm{M}, 55 \\
\text { (Before } \\
\text { bypass) }\end{array}$ & $\begin{array}{l}\text { Control } \\
\text { Angina } \\
(3+, 160) \\
\text { Recovery }\end{array}$ & $\begin{array}{r}\text { ND } \\
27\end{array}$ & $\begin{array}{l}+55 \% \\
-60 \% \\
+58 \%\end{array}$ & $\begin{array}{l}2.63 \\
3.70\end{array}$ & $\begin{array}{l}216 \\
270\end{array}$ & $\begin{array}{l}1.8 \\
2.1\end{array}$ & $\begin{array}{l}132 \\
134\end{array}$ & $\begin{array}{l}4.2 \\
4.3\end{array}$ \\
\hline 5. M, 44 & $\begin{array}{l}\text { Control } \\
\text { Angina } \\
\quad(2+, 176) \\
\text { Recovery }\end{array}$ & $\begin{array}{l}4 \\
9\end{array}$ & $\begin{array}{r}+24 \% \\
0 \% \\
+21 \%\end{array}$ & $\begin{array}{l}3.24 \\
4.32\end{array}$ & $\begin{array}{l}280 \\
320\end{array}$ & $\begin{array}{l}1.7 \\
2.1\end{array}$ & $\begin{array}{l}138 \\
142\end{array}$ & $\begin{array}{l}4.5 \\
4.8 \\
.\end{array}$ \\
\hline 6. M, 51 & $\begin{array}{l}\text { Control } \\
\text { Angina } \\
\qquad(4+, 125)\end{array}$ & $\begin{array}{r}\text { ND } \\
46\end{array}$ & $\begin{array}{l}+77 \% \\
-19 \%\end{array}$ & $\begin{array}{l}3.24 \\
3.51\end{array}$ & $\begin{array}{l}206 \\
166\end{array}$ & $\begin{array}{l}1.3 \\
1.3\end{array}$ & $\begin{array}{l}139 \\
142\end{array}$ & $\begin{array}{l}2.8 \\
2.8\end{array}$ \\
\hline 7. M, 66 & $\begin{array}{l}\text { Control } \\
\text { Angina } \\
\quad(4+, 120) \\
\text { Recovery }\end{array}$ & $\begin{array}{r}\text { ND } \\
13\end{array}$ & $\begin{array}{l}+34 \% \\
-65 \% \\
+13 \%\end{array}$ & $\begin{array}{l}3.24 \\
2.72\end{array}$ & $\begin{array}{l}280 \\
260\end{array}$ & $\begin{array}{l}1.7 \\
2.1\end{array}$ & $\begin{array}{l}135 \\
137\end{array}$ & $\begin{array}{l}4.4 \\
4.5\end{array}$ \\
\hline 8. $M, 48$ & $\begin{array}{l}\text { Control } \\
\text { Angina } \\
\qquad(2+, 200) \\
\text { Recovery }\end{array}$ & $\begin{array}{l}\text { ND } \\
\text { ND }\end{array}$ & $\begin{array}{l}+23 \% \\
-26 \% \\
+23 \%\end{array}$ & $\begin{array}{l}2.16 \\
1.62\end{array}$ & $\begin{array}{l}156 \\
173\end{array}$ & $\begin{array}{l}3.7 \\
3.5\end{array}$ & $\begin{array}{l}138 \\
138\end{array}$ & $\begin{array}{l}5.0 \\
4.6\end{array}$ \\
\hline 9. M, 59 & $\begin{array}{l}\text { Control } \\
\text { Angina } \\
\quad(4+, 140)\end{array}$ & 36 & $\begin{array}{l}+15 \% \\
-32 \%\end{array}$ & 3.24 & 290 & 2.3 & 136 & 5.3 \\
\hline & Recovery & ND & $+12 \%$ & 3.78 & 257 & 2.2 & 135 & 4.7 \\
\hline 10. $M, 58$ & $\begin{array}{l}\text { Control } \\
\text { Spontaneous } \\
\text { Angina (4+) }\end{array}$ & 83 & $\begin{array}{l}+14 \% \\
-48 \%\end{array}$ & 5.40 & 310 & 1.5 & 138 & 4.6 \\
\hline & Recovery & 44 & $+12 \%$ & 6.50 & 363 & 1.9 & 139 & 4.5 \\
\hline 11. F, 61 & $\begin{array}{l}\text { Control } \\
\text { Angina } \\
\quad(4+, 148) \\
\text { Recovery }\end{array}$ & $\begin{array}{r}\text { ND } \\
35\end{array}$ & $\begin{array}{r}+21 \% \\
-78 \% \\
0 \%\end{array}$ & $\begin{array}{l}2.16 \\
2.16\end{array}$ & $\begin{array}{l}180 \\
210\end{array}$ & $\begin{array}{l}0.8 \\
3.0\end{array}$ & & \\
\hline 12. $M, 51$ & $\begin{array}{l}\text { Control } \\
\text { Angina } \\
\quad(2+, 176) \\
\text { Recovery }\end{array}$ & $\begin{array}{r}\text { ND } \\
5\end{array}$ & $\begin{array}{l}+21 \% \\
-6 \% \\
-26 \%\end{array}$ & $\begin{array}{l}2.72 \\
3.78\end{array}$ & $\begin{array}{l}270 \\
300\end{array}$ & $\begin{array}{l}1.8 \\
2.0\end{array}$ & $\begin{array}{l}130 \\
131\end{array}$ & $\begin{array}{l}3.9 \\
4.1\end{array}$ \\
\hline
\end{tabular}

1450 A. C. Fox, G. E. Reed, E. Glassman, A. J. Kaltman, and B. B. Silk 
TABLE I-(Continued)

\begin{tabular}{|c|c|c|c|c|c|c|c|c|}
\hline \multirow[b]{3}{*}{ Patient } & \multirow[b]{3}{*}{ Conditions* } & \multicolumn{7}{|c|}{ cs } \\
\hline & & \multirow[b]{2}{*}{ Adenosine } & \multirow[b]{2}{*}{ Lactate } & \multicolumn{2}{|c|}{ Enzymes } & \multirow[b]{2}{*}{ Creatine } & \multirow[b]{2}{*}{$\mathrm{Na}^{+}$} & \multirow[b]{2}{*}{$\mathbf{K}^{+}$} \\
\hline & & & & CPK & LDH & & & \\
\hline & & $\begin{array}{l}n \mathrm{~mol} / \\
100 \mathrm{ml} \\
\text { blood }\end{array}$ & $\begin{array}{c}(A-C S / A) \\
\times 100\end{array}$ & \multicolumn{2}{|c|}{$U / m l$ serum } & $\underset{\text { plasma }}{\mu m o l / 100 \mathrm{ml}}$ & \multicolumn{2}{|c|}{ meq/liter serum } \\
\hline 13. M, 49 & $\begin{array}{l}\text { Control } \\
\text { Angina } \\
\quad(3+, 158) \\
\text { Recovery }\end{array}$ & $\begin{array}{r}\text { ND } \\
85\end{array}$ & $\begin{array}{r}+10 \% \\
-121 \% \\
-35 \%\end{array}$ & $\begin{array}{l}2.70 \\
2.70\end{array}$ & $\begin{array}{l}263 \\
260\end{array}$ & $\begin{array}{l}3.8 \\
2.3\end{array}$ & $\begin{array}{l}140 \\
135\end{array}$ & $\begin{array}{l}4.1 \\
4.5\end{array}$ \\
\hline \multirow[t]{2}{*}{ 14. $M, 35$} & $\begin{array}{l}\text { Control } \\
\text { Angina } \\
\quad(4+, 175)\end{array}$ & 120 & $\begin{array}{l}+16 \% \\
-65 \%\end{array}$ & 3.79 & 323 & 3.3 & 138 & 4.4 \\
\hline & Recovery & ND & $+43 \%$ & 3.79 & 270 & 1.7 & 138 & 4.2 \\
\hline \multirow[t]{2}{*}{ 15. $\bar{M}, 55$} & $\begin{array}{l}\text { Control } \\
\text { Angina } \\
\quad(4+, 120)\end{array}$ & 50 & $\begin{array}{l}+15 \% \\
-32 \%\end{array}$ & 1.08 & 380 & 7.5 & 136 & 4.9 \\
\hline & Recovery & ND & $+12 \%$ & 1.62 & 320 & 3.7 & 136 & 4.2 \\
\hline Control and Recovery & \multicolumn{2}{|c|}{ Means and SE } & $+22 \% \pm 4$ & $3.07 \pm 0.34$ & $252 \pm 16$ & $2.2 \pm 0.3$ & $136 \pm 1$ & $4.4 \pm 0.2$ \\
\hline \multicolumn{2}{|l|}{ Angina } & $40 \pm 9$ & $-44 \% \pm 9$ & $3.10 \pm 0.29$ & $263 \pm 19$ & $2.8 \pm 0.5$ & $137 \pm 1$ & $4.5 \pm 0.2$ \\
\hline \multicolumn{2}{|l|}{ Significance } & $P<0.001$ & $P<0.001$ & NS & NS & NS & NS & $P<0.05$ \\
\hline
\end{tabular}

* The intensity of anginal pain $(1+$ to $4+)$ and the ventricular rate at which it was induced are indicated in parentheses. Control and recovery rates were all at resting levels and usually less than one-half the paced rates.

$\ddagger N D=$ Not detectable; NS, not significant.

Of four patients examined (no. 8, 9, 10, and 15), only nos. 10 and 15 produced inosine and hypoxanthine during angina and in very small amounts, in contrast to the findings after transient ischemia in dogs (3).

$P_{1}$ and $c-A M P$. $\mathrm{P}_{1}$ was measured in CS plasma from patients 8,9 , and 15 and was increased slightly during angina. Control values were $2.5,1.6$, and $1.9 \mathrm{mg} / 100 \mathrm{ml}$ serum; during angina the corresponding values were $3.2,3.0$, and $2.7 \mathrm{mg} / 100 \mathrm{ml}$ serum.

c-AMP was measured in CS blood in patients 9, 10, and 15 and was unchanged during angina. Control values were $44.2,40$, and $32.4 \mathrm{pmol} / \mathrm{ml}$; during angina, the values were 42,42 , and $32.4 \mathrm{pmol} / \mathrm{ml}$, respectively.

\section{Control groups \\ Group B}

Nine patients with histories of angina pectoris and with significant obstructive coronary artery disease developed no angina or only questionable angina during atrial pacing equivalent to or exceeding the rates and durations which caused angina in the preceding group. None of these patients produced significant amounts of lactate, and none released detectable levels of adenosine (Table II). No significant changes occurred during pacing in CS levels of $\mathrm{LDH}, \mathrm{CPK}, \mathrm{Cr}, \mathrm{Na}^{+}$, or $\mathrm{K}^{+}$ (Table II). In patient no. 8, control blood contained $51 \mathrm{pmol} \mathrm{c}-\mathrm{AMP} / \mathrm{ml}$ and $2.7 \mathrm{mg} \mathrm{P}_{1} / 100 \mathrm{ml}$; with pacing, the levels were unchanged, at $51 \mathrm{pmol} \mathrm{c}-\mathrm{AMP} / \mathrm{ml}$ and $2.9 \mathrm{mg} \mathrm{P} / 100 \mathrm{ml}$.

Patients 2, 3, and 6 had severe stenoses of three major coronary arteries; patients 1 and 9 had severe stenoses of two; patients 7 and 8 had severe stenosis of one major artery. Patient 6 had recurrent angina despite previous direct myocardial implantation of both internal mammary arteries. The extent of coronary artery disease in these seven patients did not, therefore, differ substantially from that in the patients of group A (Table I) who developed angina during pacing. Patient 5 had a single saphenous vein graft, bypassing an isolated severe obstruction of the anterior descending coronary artery. Patient 4 in Tables I and II is the same individual and of interest. He produced adenosine and lactate during angina induced by pacing before saphenous vein bypass of three coronary arteries. 12 days after bypass, when his heart was paced at an equal rate, 


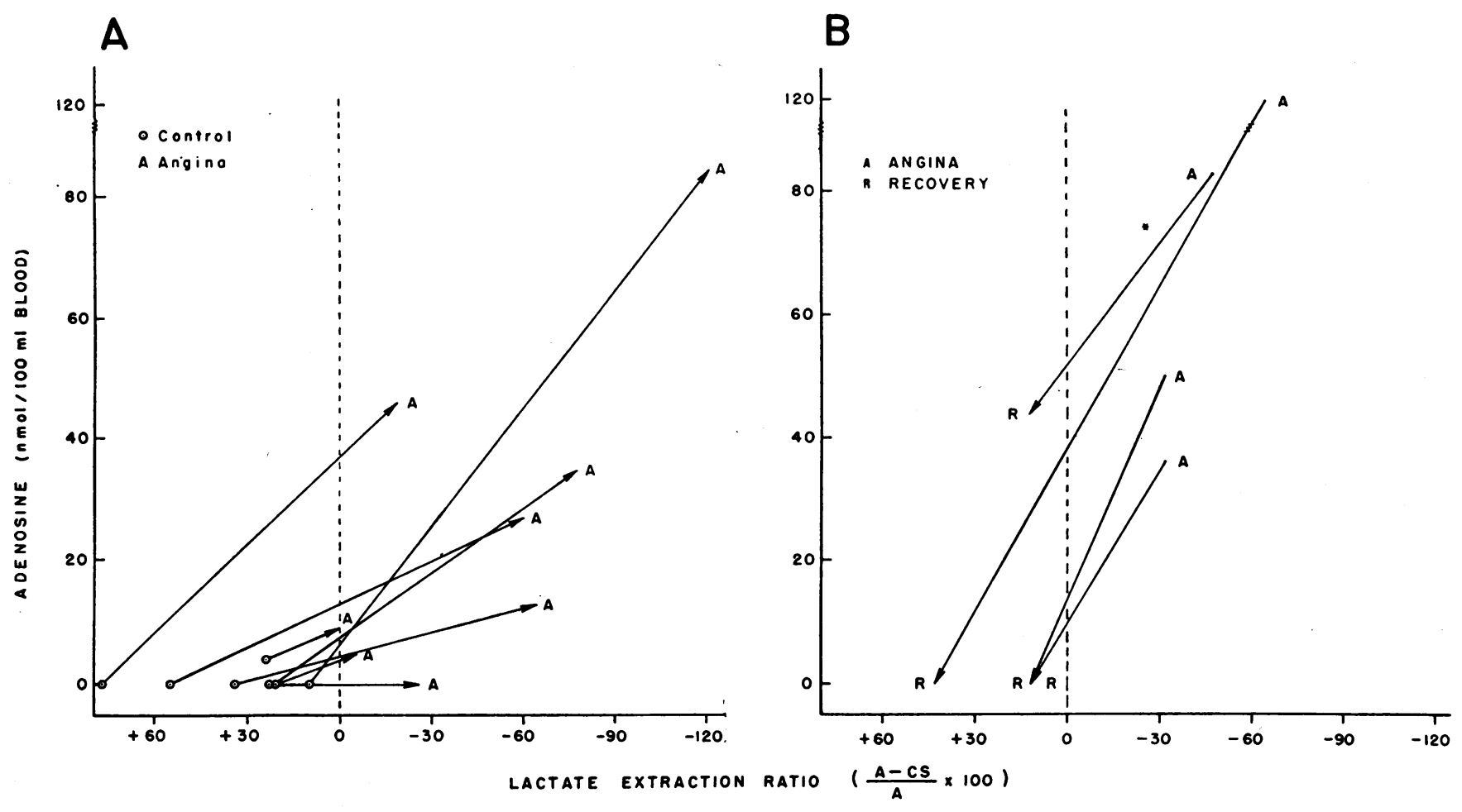

FIGURE 1 (A) Relationships between adenosine content of CS blood and myocardial lactate extraction ratio during control period and during angina induced by atrial pacing. (B) Similar relationships during angina and during recovery period. Production of lactate during angina, indicated by a negative extraction ratio or a marked shift from a positive value, was associated with production of adenosine in 11 of 12 patients. Of eight control samples, one contained a small amount of adenosine. Of four recovery samples, the one containing adenosine was from a patient with preinfarction angina $(*)$. Adenosine levels of $(0)$ indicate that adenosine was not detectable by the analytic techniques used.

he did not develop angina, produced far less lactate and no adenosine.

\section{Group C}

Five patients with questionable histories of angina or heart disease had normal coronary arteries and no significant heart disease. Three were subjected to rapid atrial pacing equivalent in rate and duration to that in the preceding two groups; two exercised strenuously on bicycle ergometers and achieved high ventricular rates (Table III). None of this group produced lactate or released detectable amounts of adenosine, and none showed significant increases in CS levels of LDH, CPK, or $\mathrm{Cr}$ during pacing or exercise (Table III).

\section{Group D}

Four patients with severe congestive heart failure and normal coronary arteriograms were studied to determine whether ventricular failure by itself could cause release of adenosine. All had elevated left ventricular diastolic pressures; $(A-\bar{V}) O_{2}$ differences were elevated at rest in three and widened abnormally in all, with exercise or pacing. None released detectable amounts of adenosine at rest, during rapid pacing, or during exercise (Table IV). In patient no. 3 , who had severe alcoholic cardiomyopathy, levels of CPK and $\mathrm{K}^{+}$were elevated in CS blood, but adenosine was not detected.

\section{DISCUSSION}

The identification of adenosine in coronary venous blood was conclusive. Other nucleosides and nucleotides were separated chromatographically and did not affect the specific enzymatic assay. Hemolysis was an unlikely source, since erythrocytes contain no detectable adenosine, have high concentrations of adenosine deaminase $(15,16)$, and did not yield adenosine after hemolysis. The concentrations of adenosine recovered during induced angina equalled or exceeded those recovered from dog hearts in the. immediate postischemic period by others (3) and by us. Although we had anticipated greater loss of adenosine in human studies, because of slower sampling through long cardiac catheters, this was 
TABLE II

Patients with Anginal Syndrome and Severe Coronary Atherosclerosis: No Angina, or Questionable Angina, and No Production of Lactate Induced by Rapid Atrial Pacing

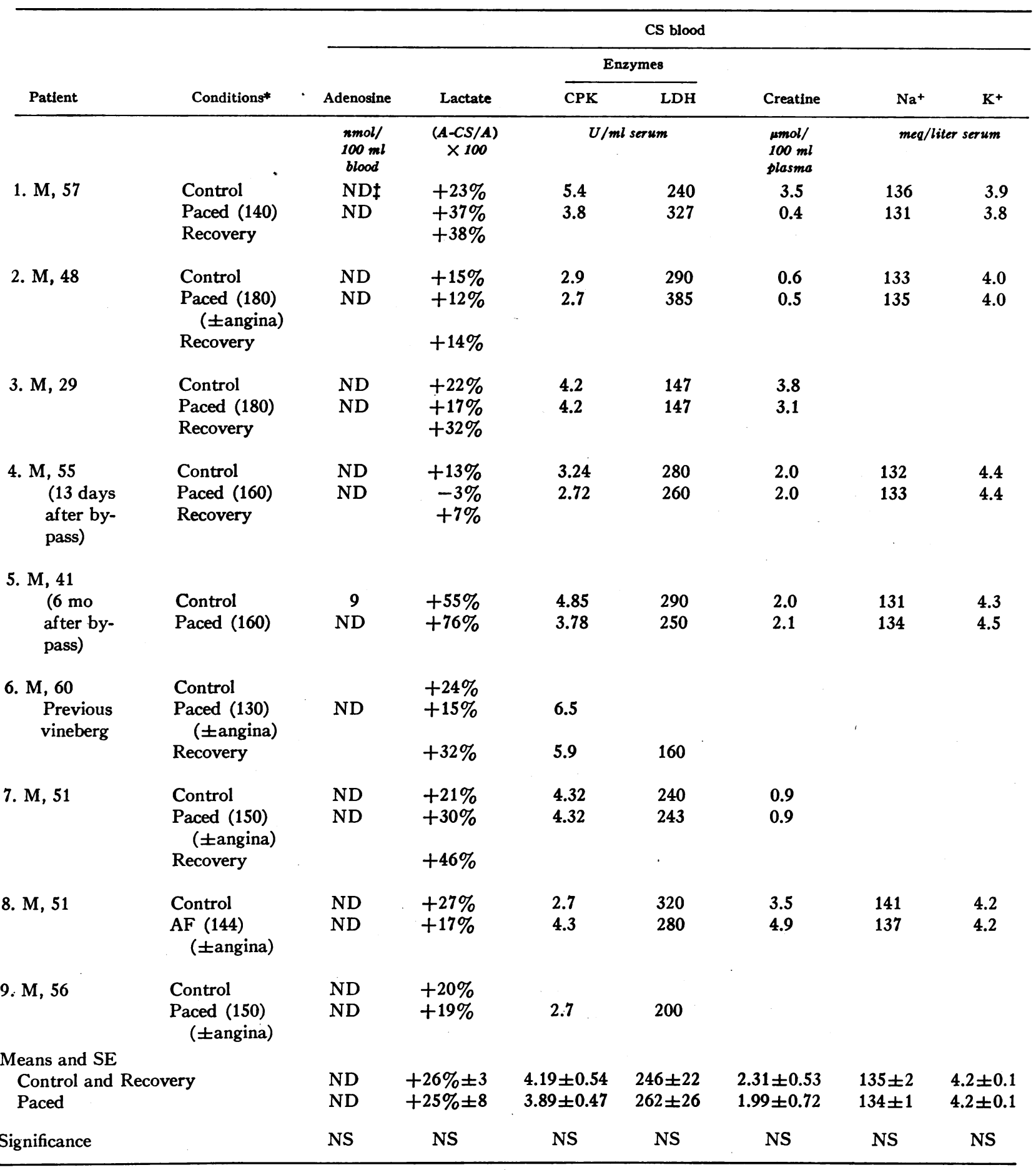

* Ventricular rate induced by atrial pacing is indicated in parentheses. Maximal tachycardia was maintained for 10 min. Control and recovery rates were all at resting levels and less than one-half the paced rate.

$\ddagger N D=$ not detectable; NS, not significant. 
TABLE III

Patients with No Significant Coronary Atherosclerosis or Hemodynamic Abnormalities

\begin{tabular}{|c|c|c|c|c|c|c|c|c|}
\hline \multirow[b]{3}{*}{ Patient } & \multirow[b]{3}{*}{ Conditions* } & \multicolumn{7}{|c|}{ CS blood } \\
\hline & & \multirow[b]{2}{*}{ Adenosine } & \multirow[b]{2}{*}{ Lactate } & \multicolumn{2}{|c|}{ Enzymes } & \multirow[b]{2}{*}{ Creatine } & \multirow[b]{2}{*}{$\mathrm{Na}^{+}$} & \multirow[b]{2}{*}{$\mathrm{K}^{+}$} \\
\hline & & & & CPK & LDH & & & \\
\hline & & $\begin{array}{l}n \mathrm{~mol} / \\
100 \mathrm{ml} \\
\text { blood }\end{array}$ & $\begin{array}{c}(A-C S / A) \\
\times 100\end{array}$ & \multicolumn{2}{|c|}{$U / m l$ serum } & $\begin{array}{l}\text { umol/ } \\
100 \mathrm{ml} \\
\text { plasma }\end{array}$ & \multicolumn{2}{|c|}{ meq/liter serum } \\
\hline $\begin{array}{r}\text { 1. M, } 20 \\
\text { (Idiopathic } \\
\text { clubbing) }\end{array}$ & $\begin{array}{l}\text { Control } \\
\text { Exercise }(16 \mathrm{~min} \\
\quad \text { at } 180)\end{array}$ & $\overline{\mathrm{ND}}$ & - & $\begin{array}{l}7.03 \\
3.89\end{array}$ & $\begin{array}{l}197 \\
183\end{array}$ & & & \\
\hline $\begin{array}{l}\text { 2. F, } 57 \\
\begin{array}{l}\text { (minimal } \\
\text { mitrial re- } \\
\text { gurgitation }\end{array}\end{array}$ & $\begin{array}{l}\text { Control } \\
\text { Exercise }(6 \mathrm{~min} \\
\quad \text { at } 120)\end{array}$ & $\overline{\mathrm{ND}}$ & - & $\begin{array}{l}3.35 \\
3.0\end{array}$ & $\begin{array}{l}131 \\
129\end{array}$ & & & \\
\hline $\begin{array}{l}\text { 3. M, } 31 \\
\text { (? history } \\
\text { of angina) }\end{array}$ & $\begin{array}{l}\text { Control } \\
\text { Paced }(10 \mathrm{~min} \\
\text { at } 160) \\
\text { Recovery }\end{array}$ & $\begin{array}{l}\text { ND } \\
\text { ND }\end{array}$ & $\begin{array}{r}\overline{0 \%} \\
+30 \%\end{array}$ & $\begin{array}{l}2.60 \\
5.60\end{array}$ & $\begin{array}{l}336 \\
383\end{array}$ & & $\begin{array}{l}137 \\
139\end{array}$ & $\begin{array}{l}4.3 \\
4.3\end{array}$ \\
\hline $\begin{array}{l}\text { 4. F, } 59 \\
\text { (? history } \\
\text { of angina) }\end{array}$ & $\begin{array}{l}\text { Control } \\
\text { Paced }(10 \mathrm{~min} \\
\text { at } 130) \\
\text { Recovery }\end{array}$ & $\begin{array}{l}\text { ND } \\
\text { ND }\end{array}$ & $\begin{array}{l}+29 \% \\
+11 \% \\
+30 \%\end{array}$ & $\begin{array}{l}2.16 \\
3.25\end{array}$ & $\begin{array}{l}163 \\
170\end{array}$ & $\begin{array}{l}1.0 \\
1.3\end{array}$ & $\begin{array}{l}138 \\
139\end{array}$ & $\begin{array}{l}4.6 \\
4.7\end{array}$ \\
\hline $\begin{array}{r}\text { 5. M, } 46 \\
\text { (? history } \\
\text { of angina) }\end{array}$ & $\begin{array}{l}\text { Control } \\
\text { Paced }(10 \mathrm{~min} \\
\text { at } 136)\end{array}$ & $\begin{array}{l}\text { ND } \\
\text { ND }\end{array}$ & $\begin{array}{l}+29 \% \\
+48 \%\end{array}$ & $\begin{array}{l}2.16 \\
3.25\end{array}$ & $\begin{array}{l}330 \\
360\end{array}$ & & $\begin{array}{l}135 \\
134\end{array}$ & $\begin{array}{l}4.7 \\
4.4\end{array}$ \\
\hline
\end{tabular}

* Duration of ventricular rate induced by pacing or exercise is indicated in parentheses.

$\ddagger N D=$ Not detectable.

apparently minimized by rapid collection and processing of blood. Since we did not detect significant amounts of inosine or hypoxanthine in man, it is possible that these nucleosides were not released in the amounts found in dogs (3) and that degradation of adenosine was not the cause of the systematic $50 \%$ losses from whole blood.

Because of the limits of sensitivity of the analytic methods, it is impossible to state that adenosine was totally absent from CS blood obtained before angina or after recovery, or from the control groups at rest or during pacing and exercise. In the latter groups it is possible that increases in total coronary flow may have caused dilution of whatever adenosine was released to undetectable levels. These data do not, therefore, permit conclusions as to the physiologic role of adenosine as a metabolic vasoregulator in normal hearts. However, the release of adenosine from arteriosclerotic hearts during induction of severe regional ischemia was definite.

The appearance of adenosine in CS blood during angina probably reflected increased concentrations of the nucleoside in the myocardium. Direct measurements of adenosine levels in dog hearts have shown that coronary occlusions for $15 \mathrm{~s}$ raised regional concentrations from $0 / 32$ to $1.82 \mathrm{nmol} / \mathrm{g}$, (5); in rats, levels rose from 6 to $128 \mathrm{nmol} / \mathrm{g}$ after $20 \mathrm{~min}$ of ischemia (17). If the levels of adenosine found in CS blood during angina are corrected for losses during analysis, calculated estimates of corresponding levels in myocardial interstitial fluid approach or exceed $56 \mathrm{nmol} / 100 \mathrm{ml}$, a level which produced maximum increases in blood flow in dogs after intracoronary injection (3).

During angina pectoris, the wide variation in levels of adenosine and lactate in CS blood could have reflected true differences in release of these substances or variable sampling due to the positions of catheters relative to coronary veins draining ischemic and nonischemic areas (18). It was not unexpected that some patients with histories of angina and with significant coronary stenoses did not develop angina during prolonged pacing. Patients with similar patterns of major coronary arterial stenoses often have different thresholds to angina (19). This may reflect differences between 
TABLE IV

Patients with No Coronary Atherosclerosis in Severe Heart Failure

\begin{tabular}{|c|c|c|c|c|c|c|c|c|}
\hline \multirow[b]{3}{*}{ Patient } & \multirow[b]{3}{*}{ Conditions* } & \multicolumn{6}{|c|}{ CS } & \multirow[b]{3}{*}{$\mathrm{K}^{+}$} \\
\hline & & \multirow[b]{2}{*}{ Adenosine } & \multirow[b]{2}{*}{ Lactate } & \multicolumn{2}{|c|}{ Enzymes } & \multirow[b]{2}{*}{ Creatine } & \multirow[b]{2}{*}{$\mathrm{Na}^{+}$} & \\
\hline & & & & $\mathrm{CPK}$ & LDH & & & \\
\hline & & $\begin{array}{c}n m o l / 100 \mathrm{ml} \\
\text { blood }\end{array}$ & $\begin{array}{l}(A-C S / C) \\
\times 100\end{array}$ & \multicolumn{2}{|c|}{$\mathrm{U} / 100 \mathrm{ml}$ serum } & $\begin{array}{c}\text { umol } / \\
100 \mathrm{ml} \text { plasma }\end{array}$ & \multicolumn{2}{|c|}{ meq/liter serum } \\
\hline $\begin{array}{l}\text { 1. } \mathrm{M}, 34 \\
\quad(\mathrm{~A}-\nabla) \mathrm{O}_{2} 4.9 \\
\text { cardiomyopathy }\end{array}$ & $\begin{array}{l}\text { Control } \\
\text { Exercise } \\
\quad 16 \mathrm{~min}(110)\end{array}$ & $\begin{array}{l}\text { ND } \ddagger \\
\text { ND }\end{array}$ & $\begin{array}{l}+10 \% \\
+50 \%\end{array}$ & $\begin{array}{l}7.6 \\
3.8\end{array}$ & $\begin{array}{l}137 \\
217\end{array}$ & - & $\begin{array}{l}127 \\
129\end{array}$ & $\begin{array}{l}3.1 \\
3.1\end{array}$ \\
\hline $\begin{array}{l}\text { 2. } \mathrm{M}, 57 \\
\quad(\mathrm{~A}-\bar{\nabla}) \mathrm{O}_{2} 6.2 \\
\quad \text { cardiomyopathy }\end{array}$ & $\begin{array}{l}\text { Control } \\
\text { Paced (140) }\end{array}$ & $\begin{array}{l}\text { ND } \\
\text { ND }\end{array}$ & $\begin{array}{l}+39 \% \\
+41 \%\end{array}$ & $\begin{array}{l}1.6 \\
2.2\end{array}$ & $\begin{array}{l}470 \\
390\end{array}$ & & & \\
\hline $\begin{array}{l}\text { 3. } \mathrm{M}, 42 \\
(\mathrm{~A}-\bar{\nabla}) \mathrm{O}_{2} 8.4 \\
\text { cardiomyopathy }\end{array}$ & $\begin{array}{l}\text { Control } \\
\text { Paced (120) }\end{array}$ & $\begin{array}{l}\text { ND } \\
\text { ND }\end{array}$ & $\begin{array}{l}+18 \% \\
+17 \%\end{array}$ & 8.3 & 627 & 1.8 & 121 & 6.0 \\
\hline $\begin{array}{l}\text { 4. } \begin{array}{l}\mathrm{M}, 49 \\
(\mathrm{~A}-\mathrm{\nabla}) \mathrm{O}_{2} 8.0 \\
\text { AI, MR, CHF }\end{array}\end{array}$ & Rest & ND & - & 1.75 & 333 & & 128 & 4.1 \\
\hline
\end{tabular}

* Ventricular rate induced by pacing or exercise is indicated in parentheses.

$\ddagger \mathrm{ND}=$ Not detectable.

individuals in the mass of ischemic tissue, in collateral circulation, in patterns of nutrient flow, or in regional metabolic requirements.

It is not clear whether the release of adenosine from the myocardium during ischemia reflects increased production of adenosine or leakage due to a specific increase in cell-wall permeability. Lactate production during ischemia probably reflects an increase in production and in transmembrane concentration gradients (20). Our findings indicate that there is at least a temporal relationship between ischemia, adenosine release, and lactate production. The absence of concomitant release of cytoplasmic enzymes suggests only that major damage to cell membranes was unlikely. Since patients with manifest left ventricular failure and normal coronary arteries did not produce adenosine, it was also unlikely that ventricular failure, per se, caused adenosine release during angina.

The release of adenosine during angina may prove useful as a sensitive supplemental index of the effects of regional ischemia on myocardial metabolism in clinical situations such as unstable angina or questionable infarction. Regional ischemia causes a prompt change in cell membrane potential, a loss of $\mathrm{K}^{+}$, a shift to anaerobiosis with production of lactate, and, as high energy phosphates are hydrolyzed, a loss of orthophosphate (1, $2)$. The increases we found in orthophosphate during angina in three patients permit no definite conclusions, but are consistent with changes noted in venous blood from ischemic canine hearts (2). Similarly, we measured $\mathrm{Cr}$ in $\mathrm{CS}$ blood as a possible index of increased intracellular levels of diffusible free $\mathrm{Cr}$, produced early in ischemia by rapid hydrolysis of $\mathrm{CrP}$, which is not diffusible $(21,22)$. Although there was a trend to release of $\mathrm{Cr}$ during angina, the increases were not statistically significant.

Fig. 2 depicts some of the processes which may regulate adenosine levels in the myocardial cell. A fall in regional levels of ATP during ischemia $(22,23,24)$ may favor conversion of AMP to adenosine by $5^{\prime}$-nucleotidase and decreases conversion to IMP by adenylate de-

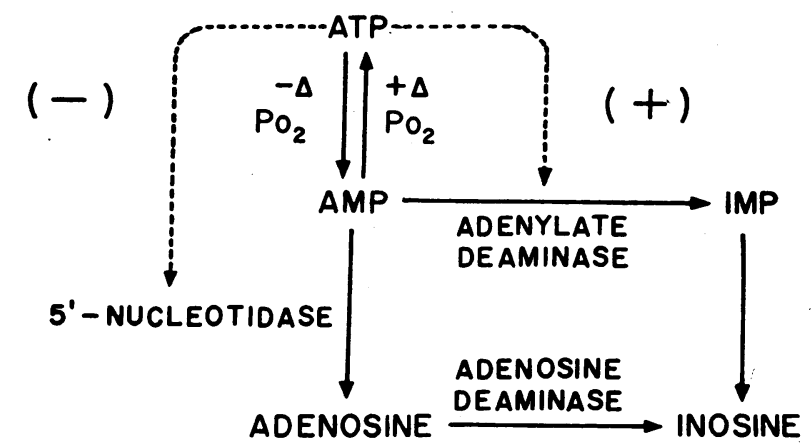

Figure 2 Possible mechanisms for regulation of levels of adenosine in the heart. Production of adenosine is favored by a fall in $\mathrm{Po}_{2}$, causing a decrease in ATP, a rise in AMP, and increased activity of $5^{\prime}$-nucleotidase. Production of IMP from AMP is favored at normal levels of ATP. 
aminase $(25,26)$. Activity of $5^{\prime}$-nucleotidase is highest at cell walls and in perivascular cells $(27,28)$. Adenosine produced in these areas may dilate resistance vessels and then may be metabolized rapidly by . red cell adenosine deaminase, removed by the venous effluent, or returned to myocardial cells by facilitated diffusion (29). During recovery from myocardial ischemia, the synthesis of nucleotides increases, perhaps to compensate for prior losses (30).

The mechanism by which adenosine dilates coronary arteries is not clear. Adenosine is probably one of many metabolic vasoregulators which act in concert to relax vascular smooth muscle in response to increased myocardial oxygen needs (31). The action of adenosine is potentiated by low $\mathrm{Po}_{2}(32,33)$ and may be mediated by "purinergic" nerve endings (34). It does not cause increased myocardial oxygen consumption, and high concentrations are negatively inotropic $(35,36)$. Although high levels of adenosine inhibit $3^{\prime}, 5^{\prime}$-phosphodiesterase (37), we found no increases in c-AMP in coronary venous blood samples taken at the time of adenosine release. The role of adenosine as a metabolic vasoregulator has been questioned, since neither aminophylline, a blocker of the vasodilator effects of infused adenosine, nor lidoflazine, a potentiator, altered postischemic reactive hyperemia (38); but these drugs may not reach the intracellular sites of endogenous adenosine production.

During angina, the pattern of changes in total coronary flow and its intramyocardial distribution are not well established; these were not examined during adenosine release in this study. Total coronary flow may increase during induced angina, perhaps as flow is increased to marginally ischemic areas by metabolically induced vasodilators (39), or it may decrease $(40,41)$. Recent investigations with precordial imaging techniques suggest that regional flow to the most ischemic areas may decrease during angina $(42,43)$.

The release of adenosine found in both man and dog (3) was related to transient myocardial ischemia produced by different but analogous means. Rapid pacing in man induced angina by increasing myocardial oxygen needs in the presence of severe restrictions to coronary flow. Reactive hyperemia was induced in dogs by temporary restriction of coronary flow, but the hyperemic response, like angina, is related to heart rate and oxygen consumption $(35,44)$ and is accompanied by lactate production (45). Reactive hyperemia has also been demonstrated in human hearts after brief occlusion and release of functioning coronary artery bypass grafts during surgery $(46,47)$.

It seems reasonable to speculate that if adenosine is truly an effective vasodilator in man, the large amounts released during, and perhaps immediately after, induced angina may have physiologic effects. Adenosine released from ischemic areas, where vasodilation is already maximal, may diffuse to marginally ischemic zones where the resultant increase in blood flow may help protect jeopardized cells. Similarly, as the reversible ischemia of angina subsides, washout of adenosine might augment regional flow and delivery of oxygen and might expedite removal of accumulated metabolites in a pattern analogous to reactive hyperemia in the dog. Improved methods for analysis of adenosine in smaller samples of blood (48) may permit more precise assessment in man of the sequential relationships between acute ischemia, evidence of anaerobic metabolism, the release of adenosine, and possible changes in regional myocardial perfusion.

\section{ACKNOWLEDGMENTS}

Sandra Kammerman, M. D., made the measurements of c-AMP.

This work was supported by USPHS (NHLI) Research Grant HE 03312 and by American Heart Association Research Grant 70-868.

\section{REFERENCES}

1. Parker, J. O., M. A. Chiong, S. T. Rowe, R. O. West, and R. B. Case. 1970. The effect of ischemia and alterations of heart rate on myocardial potassium balance in man. Circulation. 42: 205.

2. Opie, L. H., M. Thomas, P. Owen, and G. Shulman. 1972. Increased coronary venous inorganic phosphate concentration during experimental myocardial ischemia. Am. J. Cardiol. 30: 503.

3. Rubio, R., R. M. Berne, and M. Katori. 1969. Release of adenosine in reactive hyperemia of the dog heart. Am. J. Physiol. 216: 56.

4. Rubio, R., and R. M. Berne. 1969. Release of adenosine by the normal myocardium in dogs and its relationship to the regulation of coronary resistance. Circ. Res. 25: 407.

5. Olsson, R. A. 1970. Changes in content of purine nucleoside in canine myocardium during coronary occlusion. Circ. Res. 26: 301.

6. Moir, T. W., and T. D. Down. 1972. Myocardial reactive hyperemia: comparative effects of adenosine, ATP, A.DP, and AMP. Am. J. Physiol. 222: 1386.

7. Bousvaros, G. A., J. E. Campbell, and M. McGregor. 1969. Hemodynamic effects of dipyridamole at rest and during exercise in healthy subjects. Br. Heart $J$. 28: 331 .

8. Kalckar, H. M. 1947. Differential spectrophotometry of purine compounds by specific enzymes. I. Determination of hydroxypurine compounds. J. Biol. Chem. 1967 : 429.

9. Marbach, E. P., and M. H. Weil. 1967. Rapid enzymatic measurement of blood lactate and pyruvate. Clin. Chem. 13: 314.

10. Tanzer, M. L., and C. Gilvarg. 1959. Creatine and creatine kinase measurement. J. Biol. Chem. 234: 3201.

11. Berlet, M. H. 1968. Enzymatic determination of creatine in serum and cerebrospinal fluid. Clin. Chim. Acta. 20: 149 .

1456 A. C. Fox, G. E. Reed, E. Glassman, A. J. Kaltman, and B. B. Silk 
12. Wróblewski, D., and J. S. LaDue. 1955. Lactate dehydrogenase in blood. Proc. Soc. Exp. Biol. Med. 90: 210.

13. Horwitt, B. N. 1952. Determination of inorganic serum phosphate by means of stannous chloride. J. Biol. Chem. 199: 537.

14. Gillman, A. G. 1970. A protein binding assay for adenosine 3',5'-cyclic monophosphate. Proc. Natl. Acad. Sci. U. S. A. 67: 305.

15. Sugita, Y., and E. R. Simon. 1965. The mechanism of action of adenosine in red cell preservation. J. Clin. Invest. $44: 629$.

16. Schrader, J., R. M. Berne, and R. Rubio. 1972. Uptake and metabolism of adenosine by human erythrocyte ghosts. Am. J. Physiol. 223: 159.

17. Berne, R. M., R. Rubio, J. G. Dobson, Jr., and R. R. Curnish. 1971. Adenosine and adenine nucleotides as possible mediators of cardiac skeletal muscle blood flow regulation. Circ. Res. 28 (Suppl. I) : I-115.

18. Herman, M. V., W. C. Elliott, and R. Gorlin. 1967. An electrocardiographic, anatomic and metabolic study of zonal myocardial ischemia in coronary heart disease. Circulation. 35 : 834.

19. Proudfit, W. L., E. K. Shirey, W. C. Sheldon, and F. M. Sones, Jr. 1968. Certain clinical characteristics correlated with extent of obstructive lesions demonstrated by selective cine-coronary arteriography. Circulation. 38 : 947.

20. Rovetto, M. J., J. T. Whitmer, and J. R. Neely. 1973. Comparison of the effects of anoxia and whole heart ischemia on carbohydrate utilization in isolated working rat hearts. Circ. Res. 32 : 699.

21. Lee, Y. C. P., R. A. DeWall, and M. B. Visscher. 1960. State of creatine in mammalian heart muscle. Am. J. Physiol. 198: 855.

22. Olson, R. E., N. Dhalla, and C. N. Sun. 1971/72. Changes in energy stores in the hypoxic heart. Cardiology. 56 : 114.

23. Fox, A. C., N. S. Wikler, and G. E. Reed. 1965. High energy phosphate compounds in the myocardium during experimental congestive heart failure. Purine and pyrimidine nucleotides, creatine, and creatine phosphate in normal and in failing hearts. J. Clin. Invest. 44: 202.

24. Gudbjarnason, S., P. Mathes, and K. G. Ravens. 1970. Functional compartmentation of ATP and creatine phosphate in heart muscle. J. Mol. Cell. Cardiol. 1:325.

25. Burger, R., and J. M. Lowenstein. 1967. Adenylate deaminase. III. Regulation of deamination pathways in extracts of rat heart and lung. J. Biol. Chem. 242: 5281.

26. Nakatsu, K., and G. I. Drummond. 1972. Adenylate metabolism and adenosine formation in the heart. $\mathrm{Am}$. J. Physiol. 223: 1119.

27. Rubio, R., and R. M. Berne. 1970. Sites of nucleoside production in myocardial cells. Circulation. 42 (Suppl. III) : 62.

28. Borgers, M., J. Schaper, and W. Schaper. 1971. Adenosine-producing sites in the mammalian heart: a cytochemical study. J. Mol. Cell. Cardiol. 3: 287.

29. Olsson, R. A., J. A. Snow, M. K. Gentry, and G. P. Frick. 1972. Adenosine uptake by canine heart. Circ. Res. 31 : 767.
30. Zimmer, H. G., C. Trendelenburg, H. Kammermeier, and E. Gerlach. 1973. Denovo synthesis of myocardial adenine nucleotides in the rat. Acceleration during recovery from oxygen deficiency. Circ. Res. 32: 635.

31. Gregg, D. E. 1971-2. Relationship between coronary flow and metabolic changes. Cardiology. 56: 291.

32. Duling, B. R., and R. M. Berne. 1971. Oxygen and the local regulation of blood flow: possible significance of longitudinal gradients in arterial blood oxygen tissue. Circ. Res. 28 (Suppl. I) : I-65.

33. Gellai, M., J. M. Norton, and R. Detar. 1973. Evidence for direct control of coronary vascular tone by oxygen. Circ. Res. 32: 279.

34. Burnstock, G. 1972. Purinergic nerves. Pharmacol. Rev. 24: 509.

35. Bache, R. J., F. R. Cobb, and S. C. Greenfield, Jr. 1973. Effects of increased myocardial oxygen consumption on coronary reactive hyperemia in the awake dog. Circ. Res. 33: 588.

36. Buckley, N. M., K. K. Tsuboi, and N. J. Zeig. 1961. Inotropic effects of purines and pyrimidines on the isolated heart. Circ. Res. 9: 242

37. Gulyassy, P. F. 1971. Inhibition of cyclic $3^{\prime}, 5^{\prime}$-nucleotide phosphodiesterase by adenosine compounds. Life Sci. Part II Biochem. Gen. Mol. Biol. 10: 451.

38. Bittar, N., and T. J. Pauly. 1971. Myocardial reactive hyperemia responses in the dog after aminophylline and lidoflazine. Am. J. Physiol. 220: 812.

39. Conti, C. R., B. Pitt, W. D. Gundel, G. C. Freisinger, and R. S. Ross. 1970. Myocardial blood flow in pacinginduced angina. Circulation. 42: 815.

40. Yoshida, S., W. Ganz, R. Donoso, H. S. Marcus, and H. J. C. Swan. 1971. Coronary hemodynamics during successive elevation of heart rate by pacing in patients with angina pectoris. Circulation. 44: 1062.

41. Knoebel, S. B., P. L. McHenry, A. J. Bonner, and J. F. Phillips. 1973. Myocardial blood flow in coronary artery disease. Effect of right atrial pacing and nitroglycerin. Circulation. $47: 690$.

42. Zaret, B. L., H. W. Strauss, N. D. Martin, H. P. Wells, and M. D. Flamm, Jr. 1973. Noninvasive regional myocardial perfusion with radioactive potassium. N. Engl. J. Med. 288: 809.

43. Maseri, A., A. Pesola, C. Contini, and A. L'Abbate. 1973. Regional alterations of myocardial perfusion in angina pectoris. Circulation. 7(Suppl. IV) : IV-65.

44. Pauly, T. J., W. C. Zarnstorff, and N. Bittar. 1973. Myocardial metabolic activity as a determinant of reactive hyperaemia responses in the dog heart. Cardiovasc. Res. $7: 90$.

45. Olsson, R. A., and D. E. Gregg. 1965. Metabolic responses during myocardial reactive hyperemia in the unanesthetized dog. Am. J. Physiol. 208: 231.

46. Reneman, R. S., and M. P. Spencer. 1972. The use of diastolic reactive hyperemia to evaluate the coronary vascular system. Ann. Thorac. Surg. 13: 477.

47. Smith, S. C., Jr., R. Gorlin, M. V. Herman, W. J. Tyler, and J. J. Collins, Jr. 1972. Myocardial blood flow in man: effects of coronary collateral circulation and coronary artery bypass surgery. J. Clin. Invest. 51: 2556.

48. Namm, D. H., and J. L. Zucker. 1973. A new analytical procedure for the measurement of adenosine. Fed. Proc. 32: 793. (Abstr.). 